\title{
What makes for a better city? Eucharistic liturgy as social critique
}

Eric Stoddart

\begin{tabular}{|l|l|}
\hline Date of deposit & 26/05/2017 \\
\hline Document version & Author's accepted manuscript \\
\hline Access rights & $\begin{array}{l}\text { C } 2017 \text { Contact Pastoral Trust. This work is made available online } \\
\text { in accordance with the publisher's policies. This is the author } \\
\text { created, accepted version manuscript following peer review and } \\
\text { may differ slightly from the final published version. }\end{array}$ \\
\hline $\begin{array}{l}\text { Citation for } \\
\text { published version }\end{array}$ & $\begin{array}{l}\text { Stoddart, E. (2017). What makes for a better city? Eucharistic } \\
\text { liturgy as social critique. Practical Theology. }\end{array}$ \\
\hline $\begin{array}{l}\text { Link to published } \\
\text { version }\end{array}$ & https://dx.doi.org/10.1080/1756073X.2017.1340001 \\
\hline
\end{tabular}

Full metadata for this item is available in St Andrews Research

Repository at: https://research-repository.st-andrews.ac.uk/

\section{St Andrews Research Repository}




\section{What makes for a better city? Eucharistic liturgy as social critique.}

\section{Introduction}

Cities shape us, for better or worse. As a place of birth or current home, the nostalgic tales, current conditions, and aspirations of development of cities influence our identity. It may be that we reject what it supposedly means to be an Aberdonian, Glasgwegian or Londoner but, nevertheless, we are moulded.

Cities and regions compile Development Plans that aim to set the agenda (and constraints) for infrastructure and amenities into the next 10 or 15 years, and sometimes more. Their criteria around, for example, average house build rates, recycling targets, and vibrancy of an evening economy, are laudable but this paper proposes a novel approach to understanding the success of a city from a Christian perspective. It adopts the grammar of the Eucharistic liturgy to ask what makes for a better city. This gives us a means of talking about the development of a region that is not merely a response to civic and commercial criteria. Rather, the language of liturgy opens discussion of themes such as humility, handling civic failures, offering mercy, wrestling with multiple visions of the Common Good, gift rather than exchange as a model of relationships, and corporeality. The components of the Eucharistic liturgy may affirm as well as critique prevailing criteria of success and in this sense what I propose is a public liturgical practical theology.

\section{Theological Reflection on Urban Planning}

My proposals are contextualised in Edinburgh but are by no means limited in relevance only to Scotland's capital city. Similarly, whilst they draw upon a liturgy from the Scottish Episcopal Church the framework of a Eucharistic celebration will be familiar much more widely - including by those who employ the same components less in low-church traditions.

I want first to set the scholarly context for my proposal; and to draw upon the peculiarities of Edinburgh as a map through what is a diverse field of literature, and one that has had some, but as yet not a large amount of theological consideration. I will attend particularly to those authors who have focused theological reflection specifically upon urban planning: Jürgen Moltmann (in the late 1960s), Graham Ward and Seppo Kjellberg (both in 2000) and Timothy Gorringe (in 2008). This will be a prelude to the core of the article - the use of selected components of a Eucharistic liturgy to open alternative questions about developing better cities.

\section{Edinburgh - The Old Town and the New Town.}

Visitors to Edinburgh quickly become familiar with the bifurcation between the Old Town (on the spine running from the Castle to Holyrood) and the New Town (Princes Street and north). The city avoided wholesale 'renewal' in the 1950s and 1960s for the acolytes of Le Corbusier were denied the opportunity to inflict their 'creation of harmony' by way of 'the Plan' that sought to construct a new environment for a 'contemporary consciousness' (Le Corbusier, 1967, p. 182). Such grandiose, fantastical visions of modernism solving the problems of urban living came to be superseded by a plea for diversity sustainability, and generally more human-scale approaches such as those of Richard Rogers who argues for a city that is just, beautiful, creative, ecological, of easy contact and mobility, compact and polycentric, and diverse, (Rogers, 1997, pp. 167-168).

Moltmann's focus in his late 1960s piece is very much upon planning as an exercise in relation to hope rather than the substantive content of particular plans (Moltmann, 1971). The 
future, as it were, comes towards us, opening up not fate but the possibility of that which is new (novum) breaking into, and making meaningful, the freedom that is human experiencein-relation. Planning, in its familiar mode of prognosis or anticipation is, to Moltmann, theologically inadequate. Such a perspective reflects the deleterious morphing of the promise of God into the providence of God. In other words, instead of faith in a God who makes history, Christians came to believe in a God who is over history. Planning thus becomes an image of this wrongly-conceived divine providence (Moltmann, 1971, p. 184). Instead, planning, contends Moltmann, needs 'to be aware of its origin in hope and of the projection of hope' (Moltmann, 1971, p. 194). The difference is a hoped-for, rather than a planned-for, future.

A move away from technocratic, 'solutions' to planning as 'performed story' has been underway, albeit not based on theological arguments but from distrust of the attenuated modernist approach to people and process. This is well-represented in the work of Leonie Sandercock (Sandercock, 1998, 2003). She deploys the metaphor of 'mongrel cities' 'to characterize this new urban condition in which difference, otherness, fragmentation, splintering, multiplicity, heterogeneity, diversity, [and] plurality prevail' (Sandercock, 2003, p. 1).

\section{Edinburgh - 'Above' and 'Below'}

'Above' and 'below' is another way of framing Edinburgh. Robert Louise Stevenson's 'Mr Jekyll and Mr Hyde' tells of one man, two personalities. With ravines on either side of the spine from the Castle to Holyrood, connections to the New Town (on the north) and then residential developments in the south required the construction of the city's Victorian bridges. Beneath the respectability of the new street level lies the Cowgate and access to the dark, dank arches. 'Respectable' citizens might avail themselves of the salubrious pleasures beneath the Bridges. However, Marcella Althaus-Reid, writing in Edinburgh, warns of the oppressive power of 'decency', calling instead for an appreciation of the subversive indecency of God and those indecent people amongst whom God is found (Althaus-Reid, 2000, 2004). Althaus-Reid makes us question the association of the arches with depravity and the street level with moral rectitude

It just such a $21^{\text {st }}$ century sensitivity around semiotics that is at the heart of Graham Ward's significant theological treatment of the construction of the urban experience (Ward, 2000). Ward's concern is to ask how the contemporary city construes and produces various bodies, by way of its systems of signification and symbols. He does this by taking the physical body of Jesus the Christ analogically, as a means of recovering talk of the good society. All bodies, constituting and being constituted by the city, are seen analogically to Christ. This includes 'the racked and viral-ridden bodies of the sick, the engineered bodies of the beautiful, the power-hungry and disenfranchised bodies of the polis, the torn and bleeding body of the Church, the poisoned and raped body of the world and the abused body of Christ' (Ward, 2000, p. 82). The Eucharistic body of Christ is the Christ accessible to us - and which provides the prime analogical reality for Ward.

\section{Edinburgh - Dwelling and Passing Through}

Like any urban area Edinburgh is a place where people dwell and a space through which they pass. It is also a place where some only every pass through as tourists. Finnish theologian Seppo Kjellberg helps us think about the importance of countering the broader sense of 'just passing through'. Kjellberg's is a cosmocentric, rather than uniquely anthropocentric, vision of better urban planning. He advocates a 'process of emancipatory koinonia' (Kjellberg, 2000, p. 68). This is most easily understood as the opportunity of 'human self-sufficient 
detachment from the original and natural community' (Kjellberg, 2000, p. 70). Rather than focusing on safety and identity, emancipatory koinonia is more about finding ways to 'create freedom' whilst remaining deeply cognisant of, and connected together, with community (Kjellberg, 2000, p. 82). We are not entitled to merely pass through the city, or the world for that matter, as if it is our time and space alone that matters: 'we are not allowed to make others pay for our amenities' (Kjellberg, 2000, p. 97). Kjellberg's manifesto draws explicitly on the biblical theme of shalom, and it is a peace that incorporates nature as well as human relationships within the urban environment (Kjellberg, 2000, p. 107f).

\section{Edinburgh - Thick and Thin}

Elaine Graham's and Stephen Lowe, responding to the Church of England's Faithful Cities Report offer a theology of 'God taking place'. This articulates the epiphanic potential of the spatial - here, the urban environment in its material, cultural, economic, political and social forms. (Graham and Lowe are openly indebted to Sandercock's work and others who have taken the 'spatial turn' in urban studies.) Humanity, made in the image of God, is capable of transcending, without necessarily negating the material world in what is a juxtaposition of immanence and transcendence in cities (E. Graham \& Lowe, 2009, p. 55). Faith, and quite definitely not only Christian faith, is thus central for their vision of the good city - especially where the challenges of class and multiculturalism often appear insurmountable. As Graham and Lowe say, 'working for the good of the city begins and ends in the local', but local that is profoundly affected by global currents (E. Graham \& Lowe, 2009, p. 158).

Timothy Gorringe developed his theology of the built environment in 2002 placing it within the 'economy of redemption'. Redemption is a process as 'the Spirit of God in-forms and in-spires the built environment through people' (Gorringe, 2002, p. 114). God is therefore 'the inspirer of all those visions of a better human environment' (Gorringe, 2002, p. 48). Social justice - as a significant dimension of 'what it takes to make and keep human life human' is inseparable from the build environment (Gorringe, 2002, p. 22). So, whilst Gorringe says social justice is 'made concrete' we can extrapolate to also say that redemption is made concrete (Gorringe, 2002, p. 49). Such positivity about the potential of cities is but one pole of a dialetic for, as Gorringe aptly notes, 'any city is always at any one time both Babylon and Jerusalem, as we are reminded by Jesus' description of Jerusalem, the city of peace, as the one who stones the prophets (Luke 19:41)' (Gorringe, 2002, p. 140). When Gorringe turns, in 2008, to specifically address the planning process he proposes seven marks of the church that 'have implications for our shaping of the homeliness of the world, for our cities and other settlements' (Gorringe, 2008, p. 111). Gorringe can read from church to city because the former embodies, in ideal terms, God's ordering of flourishing human society: 'God the reconciler is concerned with all efforts to structure life giving community' (Gorringe, 2008, p. 101).

Gorringe, and others, are positive about the potential for cities, unlike Jacques Ellul. It is Ellul who represents the gut instinct of many, particularly Protestant, Christians who find the urban environment to be particularly thick. For example, Hiel of Bethel rebuilds Jericho (1 Kings 16:34) because he wants a powerful city. 'He,' says Ellul, 'chose human modes of decision (political power and military garrison) in spite of God's word' (Ellul, 2003 [1970], p. 28). Hiel was seduced by the idea of city (Ellul, 2003 [1970], p. 30). Cities are not only symbolic of humanity's break with God (like that of King Rehoboam) but exacerbate the break with God.

\section{Not letting the city mess with one's mind.}


To see a dimension of redemption in concrete (or any other building material for that matter) is significant. However, to view the city positively within 'the economy of redemption' is not a naïve, cheer-leading-for-VisitScotland theological position. Cities do mess with our minds. Cities do shape us; forming the people who might indeed aim to be its constructive critics. Cities, however, do not engulf us or determine our critical faculties - at least not if we are careful. As Daniel Boscaljon correctly argues, 'theology is framed by our dwelling places, and true dwelling requires theology' (2013, p. 96).

But how are we to retain not merely our critical faculties within the city - but retain our critical theological faculties? Ellul is right, the city (as a way of thinking) too-easily becomes the horizon within which we can frame our criticisms (Ellul, 1965, pp. 85, 97). We require a standpoint that imaginatively transports us beyond the city to a sphere of redemption, even sanctuary of refuge, where meaning, memory, and significance are performed in a rather different mode. I propose that it is in the language of the Eucharistic liturgy that a standpoint outside urbanism exists, and a language which Christians inhabit. It is this grammar that offers us scope to shape a theological development plan for the city; a plan that is not framed only within the imaginary of the city.

\section{Eucharistic Liturgy as a Critique of the City.}

\section{The Approach - the stance of the city.}

'I will go unto the altar of God.'

'Even unto the God of my joy and gladness.'

This liturgy opens with a summons to stop and acknowledge our proper place; the act is one of humble approach. Pride and hubris are confronted and disarmed in the face of that which is Other. We can make this concrete by asking what do the avenues of approach to the epicentre of Edinburgh convey - or intend to convey? From so many points in the city you can see the Castle. Great vistas up from Inverleith and Comley Bank converge on the re-assuring outline of Edinburgh Castle; the symbolic, if not geographical, centre of the city. The Western Approach Road is not, I acknowledge particularly glamorous. Furthermore, I do not wish to airbrush out the hotch-potch of cluttered street-scape that abuts to more dignified thoroughfares. Nevertheless, I think we can ponder the extent to which a city aims to project pride, self-assurance, dominance even perhaps hubris.

\section{The Confession and the Kyrie - the city presenting its failures.}

'... We confess to God Almighty...that we have sinned in thought, word, and deed, through our own grievous fault.'

'Lord have mercy.'

Human flourishing requires space for memory (Bergmann, 2008, p. 87; Gorringe, 2008, pp. 111-112; Sandercock, 2003, pp. 221-227). The liturgy foregrounds here confession, or admission of fault - of deeds done and left undone. In the Grassmarket - at the site of so many public executions, many for political or petty reasons - there is a memorial to the lives lost in more overtly brutal times. In the local press, and in the records of Parliament, there is testimony to scandals such as in 2013 over the existence and disposal of infants' ashes at an Edinburgh and other cities' crematoria (Angiolini, 2016).

It is right to develop robust lines of accountability in public institutions. However, cultivating virtuous professionals is arguably more important. As difficult as it may be to assess, the success of a city ought surely to be interwoven with the self-reflective capacity of its public 
employees, officials and elected officers. A liturgical critique asks if there is an ethos in the corridors of civic and corporate power that promotes a healthy engagement with failure.

\section{The Absolution - the city offering mercy.}

'...May the Almighty and merciful Lord grant unto you pardon and remission of all your sins, time for true repentance, amendment of life, and the grace and comfort of the Holy Spirit...'

If 'retail therapy' is partly a search for absolution then it is effected in the assurance that one is incorporated again into the fold of the good (consumer). (Zygmunt Bauman discusses categorisation as a 'flawed consumer' as being one without the requisite disposable income to be attractive enough to advertisers, (1998).) I do not wish to be simplistic or reductionist; there are complex reasons (healthy and unhealthy) for shopping for pleasure. However, Edinburgh's retail sector, shortly to be augmented with a rebuilt 850 thousand square feet of retail, food and leisure space requires us to ask questions about economic status and absolution. ${ }^{i}$ In a climate where the most minor of infractions of the welfare benefits system incur crippling sanctions, we want to know who - and who is not - offered absolution (Church Action on Poverty et al., 2015). Some of these matters may be not in the hands of the city authorities but a liturgical critique will want to prompt a more just and merciful city - for all, and not only for some. Questioning injustice in the benefits system takes us neatly to systems of monitoring.

\section{The Collect for Purity - how the city handles its surveillance systems.}

'Almighty God, unto whom all hearts be open, all desires known, and from whom no secrets are hid: cleanse the thoughts of our hearts by the inspiration of thy Holy Spirit.'

This is what I have dubbed 'the surveillance prayer'(Stoddart, 2011, p. 41). Significantly in this liturgy it follows, rather than precedes, the confession and absolution. Such a sequence is, I suggest, theologically important because the 'surveillance prayer' is not one acknowledging God's capacity - or inclination - to catch-you-out-sinning. Rather, confession and absolution precede divine surveillance. This firmly anchors our understanding of God's gaze within God's care, instead of oppressive monitoring.

More widely, a Eucharistic liturgical critique questions the manner in which the city handles its systems of surveillance. This is much more than legal questions around privacy and human rights. It is an issue well beyond the secure and efficient management of data gathering. There can be competition in appropriating the streets (skateboarders vs elderly pedestrians) - resulting in conflict, and perhaps anti-social behaviour from feared groups (Massey, 2001). There are ways to design public spaces that reduce dark corners and encourage flows of people; ways to design-in safer environments.

Sandercock argues that the flip side of our desire to encounter the strange and surprising in cities is fear, (2003, p. 223). One result is that 'threatening' categories of people, such as destitute asylum seekers, may actually be left not surveilled because the absence of data about them keeps them lower down civic priorities, in one sense rendering them invisible. It is not always advantageous to be excluded from surveillance, (Hintjens, 2013). Equally, there are approaches that effectively militarise public space (S. D. Graham, 2010).

A liturgical critique asks practical questions about urban space and how surveillance systems are deployed. However, such ambitions require to be located within a broader context wherein human flourishing is under threat. In other words, it is to question the extent to 
which a city has given up on trust and wrapped itself in what is called a 'fabric of fear' (Walklate \& Mythen, 2008).

\section{The Gloria - the city wresting with multiple visions.}

'Glory be to God in the highest.'

Not unlike the humble approach, this component of the grammar of liturgy discloses in what it is that a city glories. Just as you might build your persona on your intellect, your dancing or baking ability, your linguistic dexterity or your tightly-honed body, so too do cities construct their identity on the world stage.

That might include some good-humoured posturing and competitiveness towards international rivals but it is a serious matter of values. In Edinburgh we might call this a cultured Scottishness (mixing both Unionism and Nationalism as befits the occasion and political wind direction). It is fair to say that there's also a 'Green' tinge to her ambitions. What, in effect, is happening is that the city is wrestling with many perspectives on the Common Good. The goal of a liturgical critique is not to set up one single understanding of the Common Good and then grade every other 'Common Good' formulation accordingly. Rather, taking the lead of Will Storrar, it is better to consider the Common Good as our way of handling our diverse understandings of it; how we argue for the substance - the freedom of open, democratic, respectful dialogue, by 'creating an open space for decision-making by mutual consent and equality of power,' (Storrar, 2014, p. 32)

I do not suggest that the grammar of liturgy proposes a theocracy or expresses a nostalgic hope for the Council to shape the City on something called 'Christian principles'. Rather, the language of liturgy accesses a Christian perspective on human flourishing and thereby asks critical questions of a city's development from outside the paradigm of civic and enterprise discourses.

\section{The Word - the city's heritage.}

That brief reminder is important because we have reached that moment in the Eucharistic liturgy when we read the Word of God. Some Christians might favour the idea of getting the Bible into Council decision-making (whether at a community, city or national level). Such a move rarely be helpful. Christians have a hard enough time interpreting the Bible amongst ourselves, let alone foisting it upon everyone as a source book for local government. Instead, this dimension of liturgical grammar involves us in dealing with one of the recognized sources of authority.

What does a city invest with authority? I am not thinking here of government legislation or statutory instruments as much as the deposit of traditions that decision-makers believe to be worthy of acknowledging. These are quite material in the form of artefacts that constitute our heritage. Our libraries and museums, for example, are custodians of our history. A liturgical critique needs to draw attention to both what is taken to be 'heritage' and how that 'heritage' is conserved. This might be ambiguous, as the example of the National Gallery of Scotland suggests. Curatorial decisions in the past meant that the Gallery 'hides' work by Scottish artists down in the remote recesses of the building on Edinburgh's Mound. As a UNESCO World Heritage Site, Edinburgh faces constraints that accompany the responsibilities of status. One would hope that civic leaders care more about heritage than its commercial value in tourism. Be that as it may, whether artefacts of books, artwork, music or other forms, and whether they be part of a national or city collection, it is important to know how a city nurtures the deposits of its revered heritage. To flourish we need a critical and careful attending to our history - and what will become our successors' history. 


\section{The Intercessions - the city's disposition towards others.}

'We pray for the world, the church and for ourselves.'

Who features in the intercessions - and who does not - tells you quite a lot about a particular Eucharistic community. Its disposition to the world is exposed in its prayers. Analogously, a city can acquire a reputation for its attitudes to those in need - whether within its own administrative boundaries or the wider world. We could well ask about a city as an advocate for others - perhaps in terms of the degree in which it welcomes refugees. Large protest marches in a city might involve a lesser proportion of residents than a small gathering in a town; but the former garners the publicity of numbers Nevertheless, intercession points towards 'standing in the gap' and how solidarity with marginalised communities might be evidenced in city life. Edinburgh Pride arguably lacks the sophisticated carnival of Glasgow's annual march. However, being the home of the Scottish Parliament clearly influences at some level the significance of protest marches - whether for Scotland's place within the EU or against President Trump's immigration restrictions.

\section{The Offertory - the city as gift.}

'Let us present our offerings to the Lord with reverence and godly fear.'

Here the bread, wine and offerings of the people are brought to the altar or Communion Table. We are not purchasing anything from God or manipulating the Divine favour. The offertory is a grammar of gift and response. Even the gifts we offer are themselves gifted to us by the gracious creativity of God.

A liturgical critique invites us to question how the notion of gift, rather than exchange, is instantiated in the built environment, and in the cultural, social and political life of the city. Granted, the radical nature of gift is challenging for capitalist economics so it might be that here is one of the most counter-cultural dimensions of a development plan. Wendy Young has made a compelling argument that the "model of markets" is becoming the single way in which people view the world, including social relationships and civic participation. For Brown this process "configures human beings exhaustively as market actors, always, only, and everywhere as homo oeconomicus" (Brown, 2015, p. 31). Similarly, Michael Sandel has challenged the motivational tactic of financial reward that has, he believes, tainted if not irreparably distorted, amongst other spheres, education (paying children to read), and entertainment (sub-contracting queuing for tickets to paid stand-ins) (Sandel, 2013 [2012]).

It thus becomes important to consider a city's voluntary and charitable sector (although regulations are largely set by national government). How are volunteering and charity work promoted in the city? This is not simply about tax-breaks but the ways in which a city (both formally by the City Council and informally by community activists) honours and values its voluntary sector. In the built environment it is more difficult to see gift instantiated but if the opposite is competitive exchange then urban design that encourages openness to sharing might be very visible and tangible signs. Public parks might, in this sense, be singularly (and theologically) important.

\section{The Consecration - the corporeality of the city's residents.}

'Take, eat, this is my Body, which is given for you.'

The Gospel of John tells us that 'the Word became flesh and dwelt amongst us'. The brutalized body of Christ whom we are invited to receive in the Eucharist anchors the liturgy as a deeply political practice. This is even more acute if we accept that 'flesh becomes word'? (Isherwood, 2001, p. 124). Such a feminist Christology confronts us with the possibility that brutalized bodies in our day might be revelatory of God's scandalous bias towards those who 
are oppressed. Whatever is our theological understanding of the consecration of the communion elements we are, I suggest, addressed by the sufferings of Christ and the sufferings of the world. At the very least, a liturgical critique has to ask how a city treats its residents' bodies. As we saw above, Graham Ward highlights corporeality in his project (2000) and Sigurd Bergman refers to maps of avoidance that show how people in a city effectively make those unlike them, and undesirable, invisible, (2008, p. 79).

We are thinking here of damp homes, support for frail and elderly bodies, or attention to abused - and self-abused - bodies. This is not to reduce people to merely their bodies - but it directs attention to the bodies of those able to afford a membership fee at Edinburgh Leisure sports facilities and to the bodies of some of my neighbours in Craigmillar whom I see emaciated and unsteady outside the corner shops.

\section{Communion - participation in city life.}

'The body of Christ.' 'The blood of Christ.'

Communion is participation in Christ and integrally linked to participation in the lives of others. As Pope John Paul II explored in Centesimus annus, to be a person - is to be a participant in others' personhood. This has political, as well as individual, dimensions where the possibilities of participation in elections and decision-making are foundational to fostering human flourishing (John Paul II, 1991, para. 46). Whilst still Karl Wojtyla, this Pope had developed a philosophy of personalism in which, 'to participate in the humanity of another being means to be vitally related to the other as a particular human being, and not just related to what makes the other (in abstracto) a human being', see (Wojtyla, 2008, p. 237). In liturgical critique we would want to consider evidence of how participation in public life, small-scale social interaction, and political challenges is being facilitated (E. Graham \& Lowe, 2009);(Archbishops' Council, 2006). Of course, this is not to advocate a totalitarian plan that seeks to dictate all areas of life. Rather, it asks about barriers to participation in Edinburgh life.

Here, the complexities of the housing market might well preclude actual participation between sectors of the population. (Those unfamiliar with Edinburgh might care to contrast movies, albeit from different times: The Prime of Miss Jean Brodie and Trainspotting I and II.) Similarly the market might hinder substantive influence upon decision-makers by people living in deprived areas of the city. To put this another way, a liturgical critique might challenge the importance to the smooth running of Edinburgh that is placed on lunches at the exclusive New Club, or rounds of golf at select courses. In other words, how does elitism and participation inter-relate in a city?

\section{Thanksgiving - thankfulness in the city.}

'O give thanks to the Lord for He is gracious. P. And His mercy endureth forever...'

We are almost at the conclusion of the Eucharist - but not before the thanksgiving. It may be that, until the most recent of times, the sin that most bothered the Church was pride.

Throughout the centuries pride was seen as the foundational sin because it closed one off from knowing one's need for God. ${ }^{\text {ii }}$ Where then might we identify thankfulness in the city? Perhaps cultural events such as Hogmanay turn people's minds to thankfulness - even if that not be necessarily in any religious sense. In the context of Edinburgh it is apposite to acknowledge the corporate-sponsored Festival Fireworks that is offered as a thank-you to the city at the end of each August.

\section{Dismissal-cultivating peace.}

'Go forth in peace.' 


\section{'Thanks be to God.'}

To sum up the evaluation of a city might be to ask how it cultivates peace. There are religious organisations that make this their particular focus through education, political campaigning and the like. Secular groups similarly advocate and empower peace-making in the wider world. Much of what is performed in the Festivals and Fringe demonstrates the power of the arts to reflect on what it means to seek peace.

\section{Conclusions}

It is tempting to talk of Christ in the Eucharist as a lens beyond which we glimpse heaven as if we are looking up through the hour-glass. The traditional, vertical gaze is important. However, we can, as it were, lay the hour-glass on its side so we are looking for heaven or life eternal as a mode of being in this world. We gaze at Christ in the Eucharistic host, then through Him to see what lies beyond the walls of the church. Christ is an interpretive lens; and an interpretive lens. We see, 'through' Him, a better city.

We cannot socially-engineer humility, self-worth, the Common Good, care for our heritage, nor attitudes of gift, participation and thankfulness, and certainly not how we treat the bodies of people in Edinburgh. Yet, our home city's built-environment, infrastructure, and development goals impact who we are, and who might yet become. The liturgical grammar of the Eucharist may seem a strange framework for engaging with a city. However, it gives us a paradigm outside that of civic and enterprise discourses. It raises different and explicitly theological themes to embody the city motto: Nisi Dominus Frustra - 'without the Lord [all is] in vain.' (Ps 127:1 'Unless the Lord builds the house, those who build it labour in vain. Unless the Lord guards the city, the guard keeps watch in vain.') The Eucharist re-claims its revolutionary (or at least subversive) dimensions, now for $21^{\text {st }}$ urban societies. This is not to advance conservative Christian culture wars but towards a fuller appreciation of human flourishing.

The proposals in this article have significance for a Christian who is a professional in, for example town planning, an architect, or civil engineer because it offers a counter being trapped in a paradigm of technical efficiency.

Our liturgical critique also has significance for Christians who are activists and campaigners engaged in a local or regional development issues. Whilst their interest is already in ecotheology and the 'environment' this chapter re-asserts the sacramentality of the built environment - albeit with emphasis on its sacramental potential.

This article has significance too for ministers in their role as Christian educators. In some ways it is a call to 'informal' Christian traditions to develop more coherent liturgy that gives serious attention to its shape and broader formational potential. On the other hand, this article is an encouragement to sacramental traditions to be bolder in their presentation of this gift to the wider church. With an authentic theology of creation that points to the sacramental potential of the built environment we might see the breaking of an individualist and ecclesial harbouring (or sequestering) of the Eucharist.

This is a liturgical public theology because there is public 'relevance' to liturgy that is practiced, forming Christian vocations in the public and commercial sphere. It is also public theology derived from liturgy. This approach offers a tool to further problematize the material and symbolic, particularly as each relates to social justice and there is no reason that other faiths could not adopt this methodology to offer liturgical critique of the city from their own forms of worship. 


\section{Bibliography}

Althaus-Reid, M. (2000). Indecent Theology: Theological Perversions in Sex, Gender and Politics. London: Routledge.

Althaus-Reid, M. (2004). From Feminist Theology to Indecent Theology. London: SCM.

Angiolini, D. E. (2016). Report of the National Cremation Investigation. Edinburghhttp://www.gov.scot/Publications/2016/07/6426/0.

Archbishops' Council, T. (2006). Faithful Cities: A call for celebration, vision and justice: The Report from the Commission on Urban Life and Faith. Peterborough \& London: Methodist Publishing House \& Church House Publishing.

Bauman, Z. (1998). Work, Consumerism and the New Poor. Buckingham: Open University Press.

Bergmann, S. (2008). Making Oneself at Home in Environments of Urban Amnesia: Religion and Geology in City Space. International Journal of Public Theology, 2(1), 70-97

Boscaljon, D. (2013). Dwelling Theologically. In D. Jasper \& D. Wright (Eds.), Theological Reflection the Pursuit of Ideas: Theology, Human Flourishing and Freedom (pp. 95-111). Farnham: Ashgate.

Brown, W. (2015). Undoing the Demos: Neoliberalism's Stealth Revolution. New York: Zone Books.

Church Action on Poverty, the Baptist Union of Great Britain, the United Reformed Church, the Methodist Church, the Church of Scotland, \& Wales, t. C. i. (2015). Time to Rethink Benefit Sanctions. Retrieved from http://www.churchpoverty.org.uk/rethinksanctions/report/reportpdf

Ellul, J. (1965). The Technological Society [La Technique ou L'Enjeu du Siecle] (J. Wilkinson, Trans.). London: Jonathan Cape.

Ellul, J. (2003 [1970]). The Meaning of the City. Eugene, OR: Wipf \& Stock.

Gorringe, T. (2002). A Theology of the Built Environment : Justice, Empowerment, Redemption. Cambridge: Cambridge University Press.

Gorringe, T. (2008). Salvation by Bricks: Theological Reflections on the Planning Process. International Journal of Public Theology, 2(1), 98-118

Graham, E., \& Lowe, S. (2009). What Makes a Good City? Public Theology and the Urban Church. London: Darton, Longman \& Todd.

Graham, S. D. (2010). Cities Under Seige: The New Military Urbanism. New York: Verson.

Hintjens, H. M. (2013). Screening In or Out? Selection Non-Surveillance of Unwanted Humanity in EU Cities. Surveillance \& Society, 11(1/2), 87-105

Isherwood, L. (2001). Introducing Feminist Christologies. London: Sheffield Academic Press.

John Paul II. (1991). Centesimus Annus.

Kjellberg, S. (2000). Urban Ecotheology. Utrecht, the Netherlands: International Books.

Le Corbusier. (1967). The Radiant City: Elements of a Doctrine of Urbanism to be Used as the Basis of Our Machine-Age Civilization. London: Faber and Faber.

Massey, D. (2001). Living in Wythenshawe The Unknown City: Contesting Architecture and Social Space (pp. 458-474). Cambridge, MA: The MIT Press.

Moltmann, J. (1971). Hope and Planning. London: SCM Press.

Rogers, R. (1997). Cities for a Small Planet. London: Faber and Faber.

Sandel, M. J. (2013 [2012]). What Money Can't Buy: The Moral Limits of Markets. London: Penguin Books.

Sandercock, L. (1998). Towards Cosmopolis: Planning for Mulitcultural Cities. Chichester: Wiley.

Sandercock, L. (2003). Cosmopolis II: Mongrel Cities in the 21st Century. London: Continuum.

Stoddart, E. (2011). Theological Perspectives on a Surveillance Society: Watching and Being Watched. Aldershot: Ashgate.

Storrar, W. (2014). The Referendum - a question of the common weal. Theology in Scotland, 21(2), 21-36

Walklate, S., \& Mythen, G. (2008). How Scared Are We? British Journal of Criminology, 48, 209255

Ward, G. (2000). Cities of God. London: Routledge. 
Wojtyla, K. (2008). The Person: Subject and Community Person and Community: Selected Essays (pp. 220-261). New York: Peter Lang.

\footnotetext{
${ }^{\mathrm{i}}$ The $£ 1 \mathrm{bn}$ redevelopment of the St James Centre includes a hotel designed to appear as if wrapped in a golden ribbon. A contentious design within a UNESCO World Heritage Site, the hotel (although now only beginning to be constructed) has been nicknamed the 'golden turd'.

ii I am indebted here to a sermon preached recently at All Saints' St Andrews Scottish Episcopal Church by David W. Brown.
} 